\title{
Structure of the oribatid mite population (Acariformes, Oribatida) in the topsoil within forest plantations in reclaimed territories (Ukraine)
}

Yuriy Kulbachko ${ }^{1}$,

Oleh Didur ${ }^{1}$,

Yuliia Ovchynnykova ${ }^{2^{*}}$

${ }^{1}$ Oles Honchar Dnipro

National University,

Gagarin Ave., 72,

Dnipro 49010, Ukraine

${ }^{2}$ Vasyl'Stus Donetsk

National University,

600-richchya St. 21,

Vinnytsia 21021, Ukraine
It has been demonstrated that coal mining leads to land degradation and devegetation with subsequent desertification of landscapes. Recently, it has become a worldwide environmental and socioeconomic problem. The presented study was performed on various stratigraphic types of artificial edaphotopes on the reclaimed site of "Pavlogradskaya" mine (Pavlograd, Dnipropetrovsk region, Ukraine) planted with eastern red cedar (Juniperus virginiana L.). The features of the structure of oribatid mite (Oribatida) population as primary destructors of dead plant material that provide such ecosystem service as improvement of soil fertility are considered. The amount of oribatid mite species varied from 17 to 26 within the studied plots in the topsoil under the red cedar. The minimal quantity of species (17 and 19, accordingly) was found in recultivated plots covered with Calcic Chernozem on the interlayer of loesslike loam and Calcic Chernozem on the interlayer of sand compared to loess-like loam topsoil (26 species). The average density of populations of oribatid mites varied from 1820 to $2887 \mathrm{ind} . / \mathrm{m}^{2}$. A higher meaning for average population density was found for Calcic Chernozem cover (from 2333 to 2887 ind. $/ \mathrm{m}^{2}$ ). In the population of oribatida in all studied artificial edaphotops under the red cedar within reclaimed forest plots, such common species as Multioppia (M.) glabra (Mihelčič, 1955), Ramusella (Rectoppia) mihelcici (Pérez-Íñigo, 1965) could be identified.

Keywords: environment reclamation, ecosystem services, pedogenesis, forest recultivation, red cedar (Juniperus virginiana L.), oribatid mites

\section{INTRODUCTION}

Mining activities are invariably associated with the disturbance of the topsoil layer in the com-

\footnotetext{
*Corresponding author. Email: yu.ovchinnikova@donnu.edu.ua
}

plex with unfavourable consequences for biota existence, such as heavy metal pollution of the atmosphere, water ecosystems, and soils (Faly et al., 2017). As a result, formation of technogenic landscapes or "industrial" deserts is taking place (Mbaya, 2013). One of the main tasks of 
ecological safety is preservation of biodiversity, prevention of desertification, and land degradation (Klymenko et al., 2017). Degradation of lands can be defined as partial or ultimate destruction of the topsoil layer, characterized by a worsening of its physiological and biological state, decrease (loss) of soil fertility, which makes agricultural use of the territory limited or impossible. The international community has long recognized the fact that land degradation, accompanied by its dehumification and devegetation, represents a huge ecological and social-economic problem.

The main target is to stop desertification and prevent or decrease the scale of land degradation and restore partially degraded lands (Chibrik et al., 2016). A large variety of modern techniques are employed for restoration of disturbed landscapes. Mainly, those techniques are oriented towards the reclamation of lands for agricultural use. If agricultural reclamation is impossible, forest recultivation is performed.

Ecological functions of soil can be good indicators of the efficiency of optimization of technogenic landscapes. One of the mechanisms of the initiation and promotion of restoration is participation of living organisms in the transformation of organic matter in soil: destruction of dead plant residues with their further humification.

Soil saprophages play a prominent role in the transformation of organic matter in the areas of forest recultivation; they are also called "ecosystem engineers" (Eisenhauer, 2010; Kul'bachko et al., 2015). Their activity is mainly connected with provision of "regulating ecosystem services", such as maintenance of soil fertility and erosion prevention. Among others, oribatid mites (Acariformes, Oribatida) contribute to the processes of soil formation (Behan-Pelletier, 1999; Kolodochka, Shevchenko, 2013; Shtirts, 2015).

In the classic sense of this group, oribatid mites (Acariformes, Oribatida) (also known as beetle mites or moss mites) comprise more than 10,000 named species representing 1239 genera and 163 families (Subías, 2012). Due to their morpho-ecological properties, oribatid mites can live in the forest floor litter, soil surfaces, and various soil horizons. Active consumption of dead plant tissues in the litter and soil horizons by oribatids provides enrichment of soil with organic matter and products of decomposition that improves water-soil properties and succession-associated changes (Bird et al., 2004; Smrž, Norton, 2004; Gormsen, 2006). Oribatids are one of the few groups of soil saprophages able to consume coniferous litter (Striganova, 1980).

Although oribatida have always attracted researchers' attention, the character of formation of their structural organization in the forest recultivation areas in semiarid condition of Ukraine has not been well studied. The present study attempts to identify the structural organization of oribatid mites in the topsoil under a red cedar plantation within the territory of the Western Donbass, which is part of the coal mining basin.

\section{MATERIALS AND METHODS}

The studied territory is located in the steppe zone of Ukraine in the Western Donbass (Fig. 1); part of the basin is situated in the territory of the Dnipropetrovsk region. In the region of the basin, there are over 40 mine seams with working thickness from 0.6 to $1.6 \mathrm{~m}$, which lie in the depth of 400 to $1800 \mathrm{~m}$. Coal extraction is performed by the open-pit mining technique. Flat piles in the 11 mines of Western Donbass contain more than 70 million of tons of phytotoxic sulphur, organic-carbon-bearing and argillaceous shale, with high content of pyrite $\left(\mathrm{FeS}_{2}\right)$, troilite $(\mathrm{FeS})$, and chalcopyrite $\left(\mathrm{CuFeS}_{2}\right)$. Movement of the deep sediments of the Cretaceous period onto the surface initiates the processes of physical weathering, oxidation, dissolution, hydrolysis, and burning. Other numerous negative factors may also induce such processes as high concentration of soluble toxic salts, rise in the alkalinity level, low absorbance and permeability, high soil density, low carbon and plant-available nitrogen concentrations (Novitskii, 2011). 


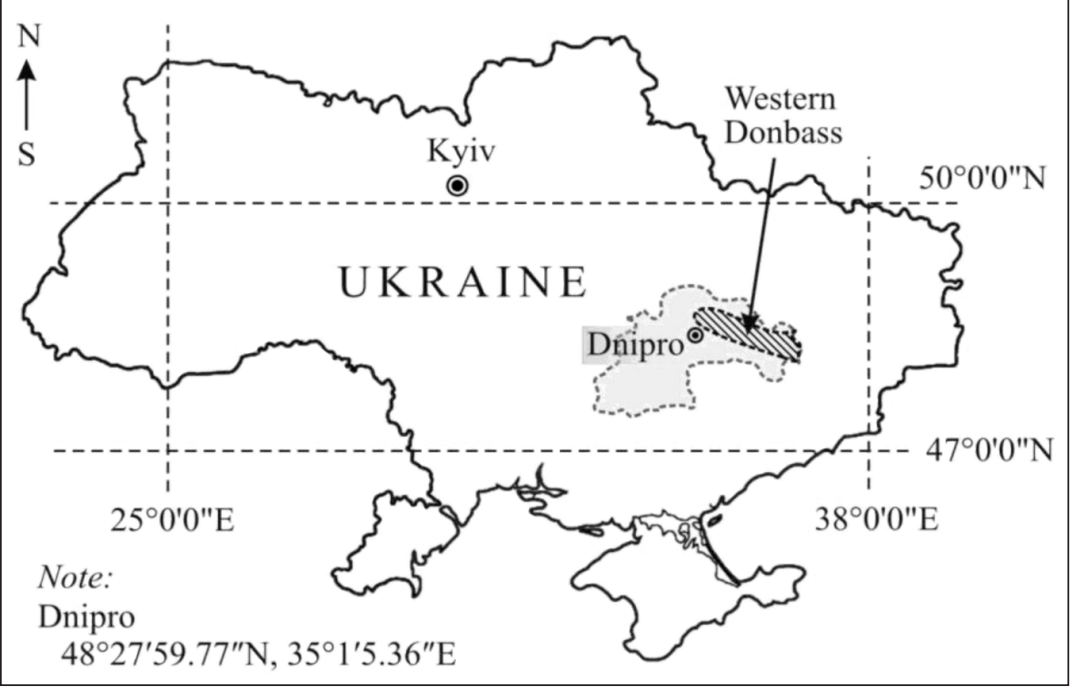

Fig. 1. Location of the Western Donbass coal basin in the Dnipropetrovsk region, Ukraine

Studied material was collected within the forest reclamation area in the territory of Western Donbass within the plantation of the red cedar (Juniperus virginiana L.) on the experimental-production reclamation plot located in the mine-field zone of "Pavlogradskaya" mine $\left(48^{\circ} 33^{\prime} 32^{\prime \prime} \mathrm{N}, 35^{\circ} 59^{\prime} 13^{\prime \prime} \mathrm{E}\right)$, where five stratigraphic types of topsoil edaphotops with different depth of the reclaimed layer were distinguished (Fig. 2).
At the stage of biological reclamation, the area was planted with trees and bushes, in particular with red cedar, an evergreen coniferous plant of the Cypress family (Cupressaceae). This popular ornamental plant is often used both for recreational areas and agromelioration and forestry.

Studies were performed in the reclamation plot with the loess-like loam topsoil (type 2) and with top layer of humified Calcic

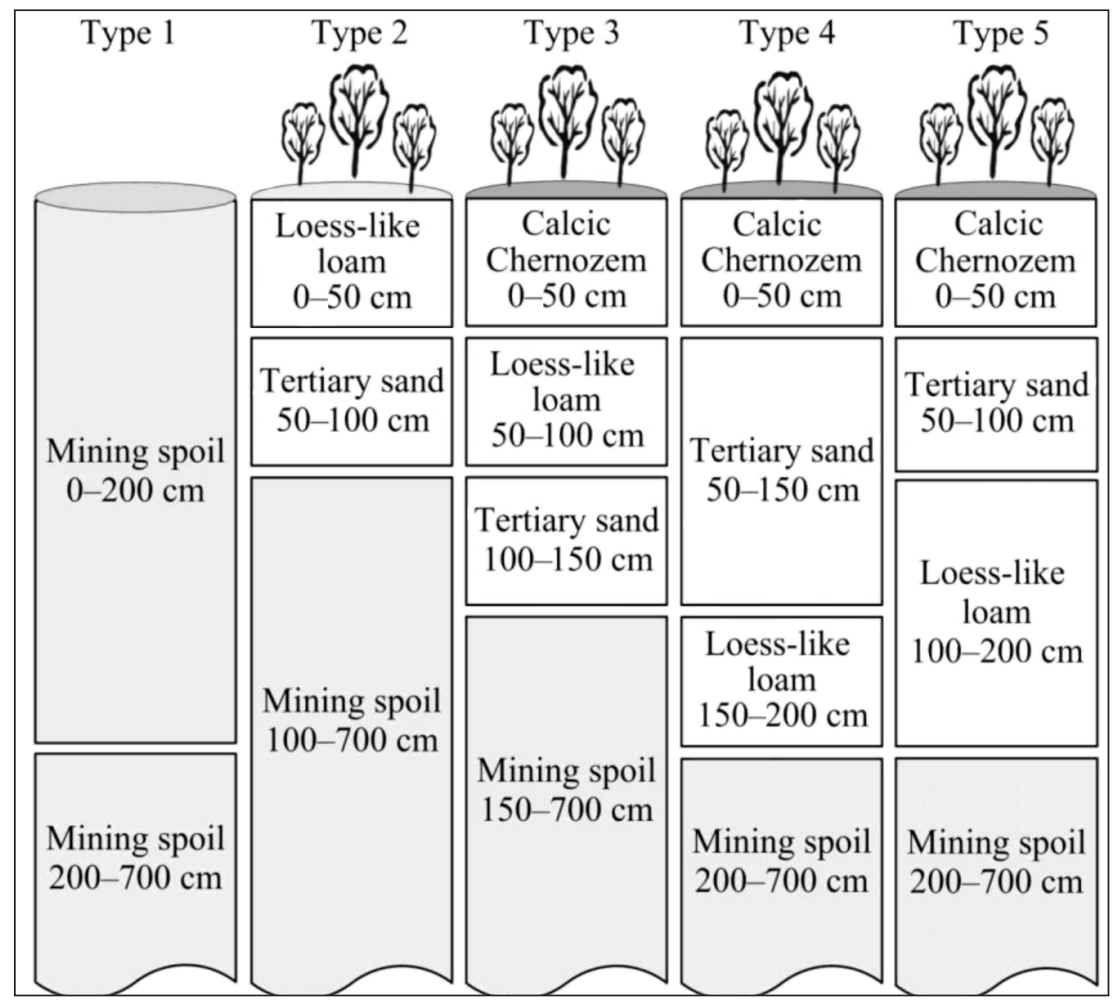

Fig. 2. Stratigraphic types of artificial edaphotopes within the experimentalproduction reclamation site 
Chernozem (types 3 and 5). Types with Calcic Chernozem had a different stratigraphic structure and were distanced from each other. The plot with Calcic Chernozem topsoil on the interlayer of loess-like loam (type 3 ) was next to the plot with loess-like loam topsoil on the sand interlayer (type 2). The plot with Calcic Chernozem topsoil on the sand interlayer (type 5) was exposed to the natural environment as it was located close to the Samara River (Dnipropetrovsk region) and surrounded by ruderal and steppe grass vegetation. The stratigraphic types had top layers of loesslike loam, which is potentially fertile (type 2), and the most fertile substrate - the upper humified layer of Calcic Chernozem (types 3, 4, $5)$. As the main mass of tree roots extend to the depth of $20-60 \mathrm{~cm}$ in the soil layer, topsoil capacity is limited to half a metre.

Collection and withdrawal of oribatida in the upper $10 \mathrm{~cm}$ layer of soil under the red cedar was performed according to the generally accepted method (Bulanova-Zakhvatkina, 1967) in 15 repeats. The composition of the oribatid species was identified by microscopy, binocular microscopes PZO (Poland) and Zeiss Promo Star (Germany) were used. For the identification of mites, "A Key to Soil-inhabiting Mites, Sarcoptiformes" (Gilyarov, 1975), "A Guide to the Ceratozetoid Mites of Ukraine" (Pavlichenko, 1994), and "Checklist of the Oribatid Mites (Acariformes, Oribatida) of the Different World Biogeographical Regions" (Subías et al., 2012) were used. For the identification of the domination structure in mite communities, the Engelmann scale was used (Engelmann, 1978): E - eudominant ( $>40 \%$ of the general amount of individuals), D - dominant (12.5-39.9\%), SD - subdominant (4.0-12.4\%), R - recedent (1.3-3.9\%), and SR - subrecedent $(<1.3 \%)$. Evaluation of the species variety index for oribatid mites was performed according to the Margalef index.

For identification of the qualitative species composition of the invertebrate communities in soil, the Jaccard coefficient of similarity was used (Magurran, 1992). In the case of ultimate absence of common species, the meaning of the coefficient is equal to zero and in the case of ultimate faunistic similarity is it equal to $100 \%$.

Mathematical processing of the obtained data was performed with MS Excel Office program tool.

\section{RESULTS AND DISCUSSION}

Environmental conditions and biotic and abiotic factors are very important for the soil biota. They define the quantity and variety of species, which, in turn, define biological diversity in general. The amount of species inhabiting a biocenosis and their ratio in population define the species structure. Indicators of importance for each particular species in the species structure of biocenosis are: its abundance (the number of individuals per unit of the inhabited area); species frequency (the percentage ratio of the points where the species was found to the general amount of the studied points); the domination ratio (the ratio between the amount of individuals of certain species and general amount of individuals in the group). These indicators have great importance for the evaluation of structure-functional characteristics of animal communities.

The present study considered the taxonomic composition, the amount of species, and the domination structure of oribatid mites on the top surface soil layers under the red cedar within three different stratigraphic types of forest recultivation plots. The features of the structure of oribatids in the loess-like loam top layer are shown in Table 1.

The analysis of the domination structure of oribatid mites inhabiting the topsoil under the red cedar within different forest reclamation types indicated that in the top layer (0$10 \mathrm{~cm}$ ) of loess-like loam (type 2), Multioppia (M.) glabra (Mihelčič, 1955) and Ramusella (Rectoppia) mihelcici (Pérez-Íñigo, 1965) were dominant species. The share of the given species was $32.2 \%$ and $15.4 \%$ of the bulk amount of individuals found on the given type, accordingly. Recedents were represented by six species, their share among all oribatid mites was $16.1 \%$. Subrecedents were represented with 14 species, 
Structure of the oribatid mite population (Acariformes, Oribatida) in the topsoil within forest plantations...317

Table 1. Species structure of the oribatid mite community inhabiting loess-like loam top layer with a sand interlayer under the red cedar plantation (stratigraphic type 2)

\begin{tabular}{|c|c|c|c|}
\hline Species & $\begin{array}{l}\text { Number of indi- } \\
\text { viduals found }\end{array}$ & $\begin{array}{c}\text { Domination } \\
\text { ratio (\%) }\end{array}$ & $\begin{array}{l}\text { Domina- } \\
\text { tion class }\end{array}$ \\
\hline Achipteria acuta Berlese, 1908 & 3 & 1.10 & SR \\
\hline Belba dubinini Bulanova-Zachvatkina, 1962 & 2 & 0.73 & SR \\
\hline Carabodes sp. Koch, 1835 & 2 & 0.73 & SR \\
\hline Dolicheremaeus montanus Krivolutsky, 1971 & 2 & 0.73 & SR \\
\hline Epilohmannia cylindrica cylindrica (Berlese, 1904) & 23 & 8.43 & SD \\
\hline Eueremaeus oblongus granulatus (Mihelčič, 1955) & 6 & 2.20 & $\mathrm{R}$ \\
\hline Galumna alata (Hermann, 1804) & 2 & 0.73 & SR \\
\hline Galumna (G.) dimorpha Krivolutskaja, 1952 & 7 & 2.57 & $\mathrm{R}$ \\
\hline Galumna (G.) lanceata (Oudemans, 1900) & 3 & 1.10 & SR \\
\hline Hermanniella sp. Berlese, 1908 & 3 & 1.10 & SR \\
\hline Gymnodamaeus bicostatus (Koch, 1835) & 16 & 5.86 & SD \\
\hline Rhinoppia obsoleta (Paoli, 1908) & 3 & 1.10 & SR \\
\hline Metabelba papillipes (Nicolet, 1855) & 3 & 1.10 & SR \\
\hline Multioppia (M.) glabra (Mihelčič, 1955) & 88 & 32.2 & $\mathrm{D}$ \\
\hline Oppiella nova (Oudemans, 1902) & 3 & 1.10 & SR \\
\hline Protoribates (P.) capucinus Berlese, 1908 & 5 & 1.83 & $\mathrm{R}$ \\
\hline Punctoribates (P.) liber Paulitchenko, 1991 & 10 & 3.66 & $\mathrm{R}$ \\
\hline Ramusella (Rectoppia) mihelcici (Pérez-Íñigo, 1965) & 42 & 15.4 & $\mathrm{D}$ \\
\hline Acrotritia hyeroglyphica (Berlese, 1916) & 2 & 0.73 & SR \\
\hline Scheloribates laevigatus (Koch, 1835) & 9 & 3.30 & $\mathrm{R}$ \\
\hline Suctobelbella (S.) acutidens acutidens (Forsslund, 1941) & 3 & 1.10 & SR \\
\hline Suctobelbella sp. Jacot, 1937 & 13 & 4.76 & SD \\
\hline Tectocepheus velatus velatus (Michael, 1880) & 7 & 2.57 & $\mathrm{R}$ \\
\hline Trichoribates trimaculatus (C. L. Koch, 1836) & 12 & 4.40 & SD \\
\hline Trichoribates (T.) novus (Sellnick, 1928) & 2 & 0.73 & SR \\
\hline Oribatula (Zygoribatula) frisiae (Oudemans, 1900) & 2 & 0.73 & SR \\
\hline Total number of individuals & 273 & & \\
\hline Total number of species & 26 & & \\
\hline Average density (ind./m²) & 1820 & - & - \\
\hline
\end{tabular}

their share was $12.8 \%$ of the whole amount of the studied mite population (Fig. 3).

Features of the species structure for oribatids identified on the upper humified layer of Chernozem on the loess-like loam interlayer are given in Table 2.

For the mite community inhabiting the Chernozem top layer on the interlayer of loess-like loam (type 3 ), three dominating spe- cies were identified: Multioppia (M.) glabra (Mihelčič, 1955) (15.7\%), Suctobelbella sp. Jacot, 1937 (15.7\%), and Epilohmannia cylindrica cylindrica (Berlese, 1904) (12.5\%) (Fig. 4). For this stratigraphic type in layer of Chernozem, the share of subdominants was equal to $50.1 \%$, recedents were not found, and the share of subrecedent species was only $6 \%$ of whole community. 


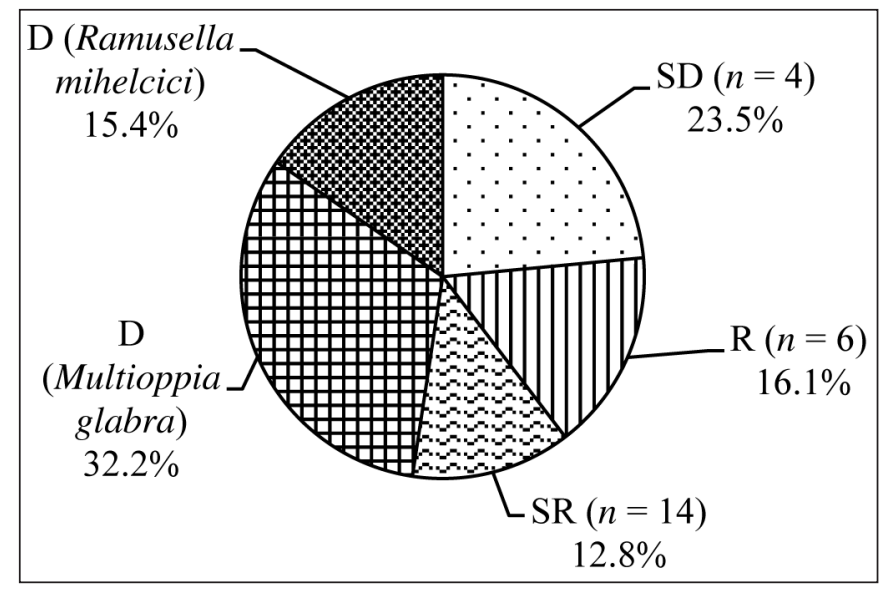

Fig. 3. Domination structure of the oribatid mite community inhabiting the loesslike loam topsoil (stratigraphic recultivation type 2)

D - dominant (12.5-39.9\% of general amount of individuals), SD - subdominant (4.0-12.4\%), R - recedent (1.3-3.9\%), SR - subrecedent $(<1.3 \%)$

Table 2. Species structure of the oribatid mite community inhabiting the top humified Chernozem layer on the interlayer of loess-like loam (stratigraphic type 3 )

\begin{tabular}{|c|c|c|c|}
\hline Species & $\begin{array}{l}\text { Number of indi- } \\
\text { viduals found }\end{array}$ & $\begin{array}{l}\text { Domination } \\
\text { ratio }(\%)\end{array}$ & $\begin{array}{l}\text { Domination } \\
\text { class }\end{array}$ \\
\hline Ceratozetes minutissimus Willmann, 1951 & 5 & 1.15 & SR \\
\hline $\begin{array}{l}\text { Epilohmannia cylindrica cylindrica (Berlese, } \\
\text { 1904) }\end{array}$ & 54 & 12.5 & $\mathrm{D}$ \\
\hline Galumna (G.) dimorpha Krivolutskaja, 1952 & 3 & 0.69 & SR \\
\hline Galumna (G.) lanceata (Oudemans, 1900) & 3 & 0.69 & SR \\
\hline Gymnodamaeus bicostatus (Koch, 1835) & 3 & 0.69 & SR \\
\hline Rhinoppia obsoleta (Paoli, 1908) & 41 & 9.47 & SD \\
\hline Metabelba papillipes (Nicolet, 1855) & 3 & 0.69 & SR \\
\hline Multioppia (M.) glabra (Mihelčič, 1955) & 68 & 15.7 & $\mathrm{D}$ \\
\hline Oppiella nova (Oudemans, 1902) & 3 & 0.69 & SR \\
\hline Protoribates (P.) capucinus Berlese, 1908 & 3 & 0.69 & SR \\
\hline Punctoribates (P.) liber Paulitchenko, 1991 & 18 & 4.16 & SD \\
\hline $\begin{array}{c}\text { Ramusella (Rectoppia) mihelcici (Pérez-Íñigo, } \\
\text { 1965) }\end{array}$ & 41 & 9.47 & SD \\
\hline Acrotritia hyeroglyphica (Berlese, 1916) & 45 & 10.4 & SD \\
\hline $\begin{array}{l}\text { Suctobelbella (S.) acutidens acutidens (Forss- } \\
\text { lund, 1941) }\end{array}$ & 27 & 6.24 & SD \\
\hline Suctobelbella sp. Jacot, 1937 & 68 & 15.7 & $\mathrm{D}$ \\
\hline Tectocepheus velatus velatus (Michael, 1880) & 45 & 10.4 & SD \\
\hline Trichoribates trimaculatus (C. L. Koch, 1836) & 3 & 0.69 & SR \\
\hline Number of individuals & 433 & - & - \\
\hline Number of species & 17 & - & - \\
\hline Average density (ind./m²) & 2887 & - & - \\
\hline
\end{tabular}




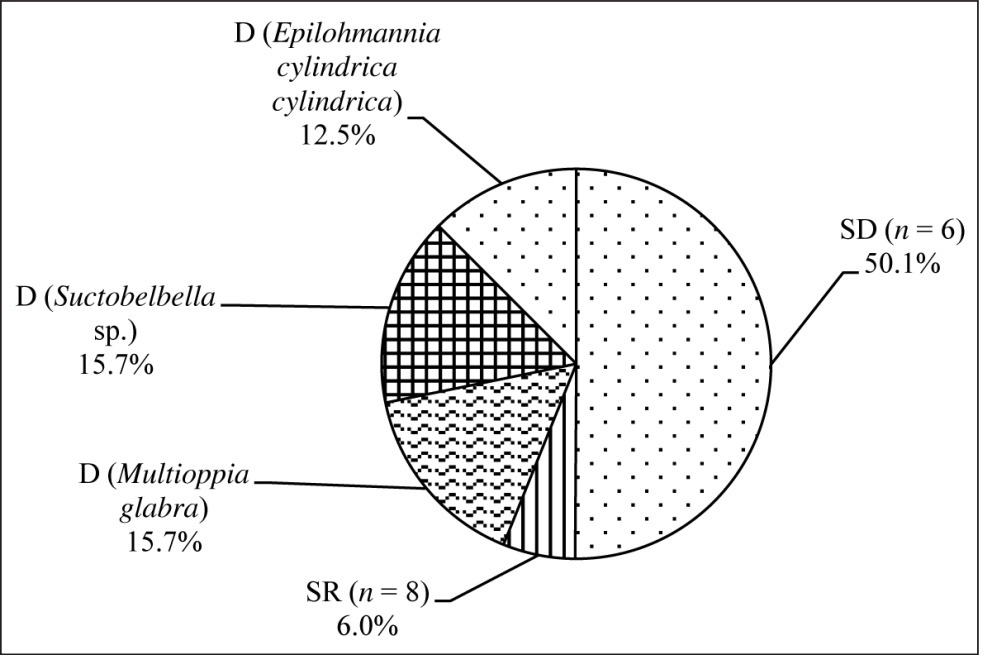

Fig. 4. Domination structure of the oribatid mite community on the humified Chernozem layer with a loess-like loam interlayer (stratigraphic recultivation type 3 )

D - dominant (12.5-39.9\% of general amount of individuals), SD - subdominant (4.0-12.4\%), SR - subrecedent $(<1.3 \%)$

Features of the species structure of the oribatid community found in the top humified Chernozem layer with a sand interlayer are presented in Table 3.

In the community of mites inhabiting the type with a humified Chernozem layer on a sand interlayer (type 5), two species were found to be dominant: Rhinoppia obsoleta (Paoli, 1908) (12.8\%) and Multioppia (M.) glabra (Mihelčič, 1955) (24.3\%) (Fig. 5). The share of the subdominant species compared to type 3 with top Chernozem layer reduced 1.6 times and amounted to $35.7 \%$ of the total number of the oribatid population. Subrecedent species were absent in this type, and the share of recedent species in the total number was $27.2 \%$. Evaluation of the domination structures of oribatid mites inhabiting top layers of loess-like loam and Chernozem indicated that on these top layers, the number of species of oribatid mites, related to the dominant class, were distributed equally $(47.6 \%, 43.9 \%$ and $37.2 \%$ on recultivation types 2,3 and 5, accordingly). The number of subdominants increases from loess-like loam $(47.6 \%, 43.9 \%$ and $37.2 \%$ for recultivation types 2,3 and 5 , respectively) to loess-like loam with a sand interlayer. The absence of subrecedent species in the Chernozem layer should be pointed out.

There was no evidence of the presence of eudominant species in Calcic Chernozem under the red cedar. The dominant species Multioppia (M.) glabra (Mihelčič, 1955) was found both in the loess-like loam top layer and in the Chernozem top layer.

An increase of $27.1 \%$ in the share of recedents in the Chernozem top layer with a sand interlayer was observed (stratigraphic type 5), while on the loess-like loam (stratigraphic type 2) the increase was estimated at rate of $16.1 \%$. No recedent species were found in the Chernozem top layer with loess-like loam interlayer (stratigraphic type 3).

Population density can be considered a measure for evaluation of the state of oribatid mite population. Comparison of the average density of oribatida under the red cedar in the topsoils of varied recultivated stratigraphic types indicated the maximal density for the Chernozem top layer on the loess-like loam interlayer (recultivation type 3 ) of $2887 \mathrm{ind} . / \mathrm{m}^{2}$ and the minimal value of 1820 ind. $/ \mathrm{m}^{2}$ was registered for the loess-like loam topsoil (recultivation type 2) (Fig. 6).

Such features of the abundance of oribatida could be explained by the properties of the studied topsoils. As petrographic analysis (the study of thin sections of topsoil samples) demonstrated (Belova, 1997) loess-like loam sample $(0-30 \mathrm{~cm})$ had many pores of biogenic origin, often filled with earthworm casts and decomposed (or partly decomposed) plant residues 
Table 3. Species structure of the oribatid mite community inhabiting the top humified Chernozem layer on a sand interlayer (stratigraphic type 5)

\begin{tabular}{|c|c|c|c|}
\hline Species & $\begin{array}{l}\text { Number of indi- } \\
\text { viduals found }\end{array}$ & $\begin{array}{l}\text { Domination } \\
\text { ratio }(\%)\end{array}$ & $\begin{array}{l}\text { Domination } \\
\text { class }\end{array}$ \\
\hline $\begin{array}{l}\text { Epilohmannia cylindrica cylindrica (Berlese, } \\
\text { 1904) }\end{array}$ & 10 & 2.86 & $\mathrm{R}$ \\
\hline Heterozetes palustris (Willmann, 1917) & 5 & 1.43 & $\mathrm{R}$ \\
\hline Rhinoppia obsoleta (Paoli, 1908) & 45 & 12.9 & $\mathrm{D}$ \\
\hline Metabelba papillipes (Nicolet, 1855) & 10 & 2.86 & $\mathrm{R}$ \\
\hline Multioppia (M.) glabra (Mihelčič, 1955) & 85 & 24.3 & $\mathrm{D}$ \\
\hline Oppiella nova (Oudemans, 1902) & 5 & 1.43 & $\mathrm{R}$ \\
\hline $\begin{array}{c}\text { Ramusella (Rectoppia) mihelcici (Pérez-Íñigo, } \\
\text { 1965) }\end{array}$ & 35 & 10.0 & SD \\
\hline $\begin{array}{l}\text { Suctobelbella (S.) acutidens acutidens (Forsslund, } \\
\text { 1941) }\end{array}$ & 5 & 1.43 & $\mathrm{R}$ \\
\hline Galumna alata (Hermann, 1804) & 5 & 1.43 & $\mathrm{R}$ \\
\hline Galumna (G.) dimorpha Krivolutskaja, 1952 & 10 & 2.86 & $\mathrm{R}$ \\
\hline $\begin{array}{c}\text { Galumna (G.) lanceata (Oudemans, 1900) (No- } \\
\text { taspis) }\end{array}$ & 5 & 1.43 & $\mathrm{R}$ \\
\hline Gymnodamaeus bicostatus (Koch, 1835) & 10 & 2.86 & $\mathrm{R}$ \\
\hline Steganacarus sp. Ewing, 1917 & 5 & 1.43 & $\mathrm{R}$ \\
\hline Acrotritia hyeroglyphica (Berlese, 1916) & 15 & 4.28 & SD \\
\hline Ceratozetella (C.) venusta (Paulitchenko, 1993) & 10 & 2.86 & $\mathrm{R}$ \\
\hline Oribatula (O.) tibialis tibialis (Nicolet, 1855) & 5 & 1.43 & $\mathrm{R}$ \\
\hline Punctoribates (P.) liber Paulitchenko, 1991 & 35 & 10.0 & $\mathrm{SD}$ \\
\hline Tectocepheus velatus velatus (Michael, 1880) & 40 & 11.4 & $\mathrm{SD}$ \\
\hline Trichoribates (T.) novus (Sellnick, 1928) & 10 & 2.86 & $\mathrm{R}$ \\
\hline Total number of individuals & 350 & - & - \\
\hline Total number of species & 19 & - & - \\
\hline Average density (ind. $/ \mathrm{m}^{2}$ ) & 2333 & - & - \\
\hline
\end{tabular}

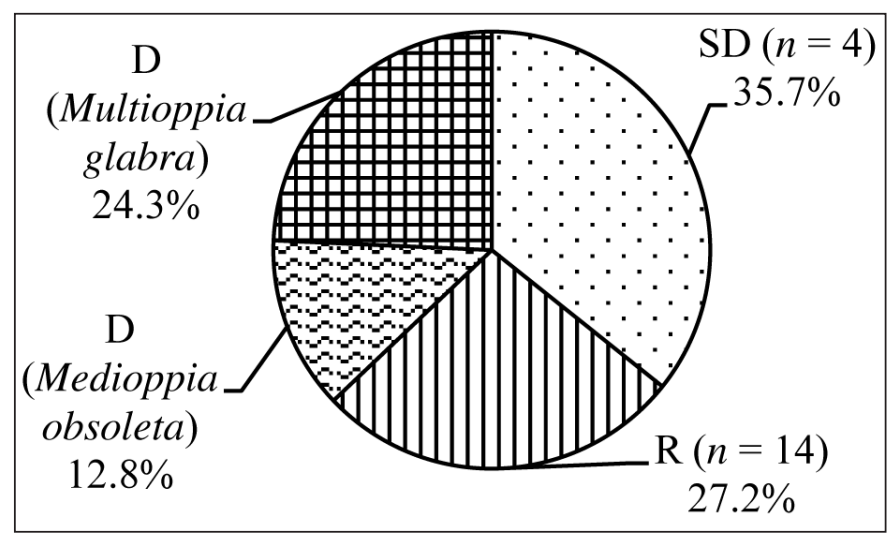

Fig. 5. Domination structure of the oribatid community in the humified Chernozem layer with a sand interlayer (stratigraphic recultivation type 5)

D - dominant (12.5-39.9\% of general amount of individuals), SD - subdominant (4.0-12.4\%), R - recedent (1.3-3.9\%) 


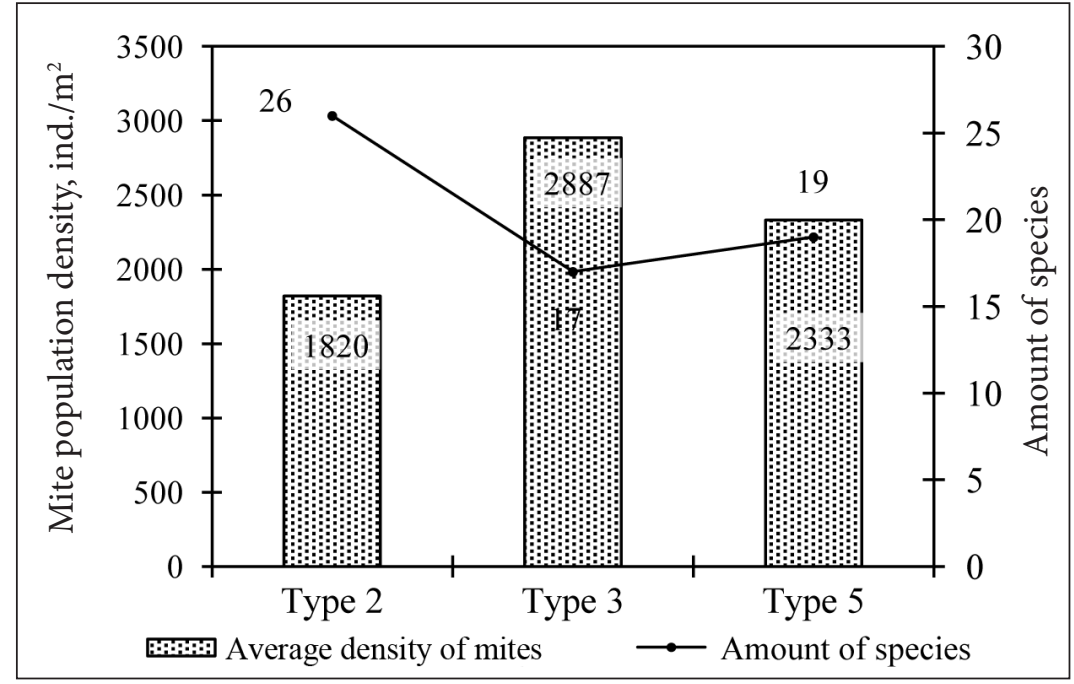

Fig. 6. Average density of the oribatid mite population and richness of species for given types of recultivation areas in topsoils $(0-10 \mathrm{~cm})$ of red cedar plantations could be found. Compared to loess-like loam, in Chernozem thin section fragments $(0-30 \mathrm{~cm})$, a high rate of aggregation of soil mass could be observed, as well as signs of soil invertebrates' activity. Many casts and pores of biogenic origin could be seen in the upper part. Described specification of the microstructure of the topsoils within the forest recultivation plots considered as favourable for the oribatida, this explains their high abundance observed in the upper layer of Chernozem on the interlayer of loesslike loam (stratigraphic type 3 ) and sand (stratigraphic type 5), resulting in better performance of its ecological functions.

It was found that in the loess-like loam topsoil (recultivation type 2), the species variety index (Margalef index) for oribatida reached the maximal meaning (4.46) compared to the Chernozem top layer (types 3 and 5, for which it had mean- ings 2.64 and 3.07, accordingly). The increase of the Margalef species variety index for oribatida inhabiting the loess-like loam topsoil and the decrease in their general abundance indicated unfinished formation of oribatid mite communities in the studied types of topsoils.

The Jaccard species similarity coefficient is widely used for comparative analysis of communities of terrestrial animals. In our research, the Jaccard species similarity coefficient calculated for oribatid mites' populations, inhabiting topsoils of three stratigraphic types indicated that rates of similarity for mites' populations had close meanings and were quite high: meanings of coefficients varied between 50.0 and 59.3\% (Table 4).

Evaluation of the similarity of the most common mite populations inhabiting loess-like loam (stratigraphic type 2) and Chernozem top layer above the interlayer of loess-like loam (strati-

Table 4. Qualitative similarity of oribatid mite communities in the bulk soils planted with red cedar on the forest recultivation plot

\begin{tabular}{c|c|c|c}
\hline Stratigraphic type of the bulk soil & $\begin{array}{c}\text { Loess-like loam } \\
\text { (type 2) }\end{array}$ & $\begin{array}{c}\text { Chernozem topsoil } \\
\text { with a loess-like loam } \\
\text { interlayer (type 3) }\end{array}$ & $\begin{array}{c}\text { Chernozem topsoil } \\
\text { with a sand interlayer } \\
\text { (type 5) }\end{array}$ \\
\hline $\begin{array}{c}\text { Loess-like loam (type 2) } \\
\begin{array}{c}\text { Chernozem topsoil with loess-like } \\
\text { loam interlayer (type 3) }\end{array}\end{array} \quad 59.3 \%$ & $16 \mathrm{~b}$ & $15 \mathrm{~b}$ \\
\hline $\begin{array}{c}\text { Chernozem topsoil with sand inter- } \\
\text { layer (type 5) }\end{array}$ & $50.0 \%$ & $17 \mathrm{a}$ & $19 \mathrm{a}$ \\
\hline
\end{tabular}

Note: $a$ - number of species of oribatid mites in $0-10 \mathrm{~cm}$ bulk layer; $b$ - number of common species for both communities 
graphic type 3) indicated the Jaccard coefficient meaning of $59.3 \%$. The least species similarity for oribatid mites in the loess-like loam and Chernozem topsoil in a sand interlayer (Jaccard coefficient meaning 50.0\%) could be explained by remote location of these types.

It was found that in the bulk soils of the studied recultivation types, the oribatid mite communities collected from under red cedar had abundant prevailing species (dominants and subdominants). Their share was quite large and varied from $71.1 \%$ to $94 \%$. The maximal sum share of species with high abundance was typical for the Chernozem topsoil with the interlayer of loess-like loam (stratigraphic type 3) - 94\%. For loess-like loam (stratigraphic type 2) and Calcic Chernozem with a sand interlayer (stratigraphic type 5), their shares in the structure of the mite population were very similar with numerical values of $71.1 \%$ and $72.9 \%$, respectively.

After recultivation, formation of oribatid mite populations in mining dumps mainly starts when species are transferred to the plot with soil masses removed from adjoining territories. The presence of common species in different topsoil types indicates high adaptive capabilities of mite populations. Among the dominant and subdominant species on the studied topsoils within forest recultivation plots, Multioppia (M.) glabra (Mihelčič, 1955) and Ramusella (Rectoppia) mihelcici (Pérez-Íñigo, 1965) were identified. Their share in the bulk of the species of high abundance was equal to $47.6 \%$ (loess-like loam type), 25.2\% (top Chernozem type on the loess-like loam interlayer), and $34.3 \%$ (top Chernozem on $a$ sand interlayer). Galumna (G.) dimorpha Krivolutskaja, 1952, Galumna (G.) lanceata (Oudemans, 1900), Metabelba papillipes (Nicolet, 1855), and Oppiella nova (Oudemans, 1902) were identified among recedent and subrecedent species on all stratigraphic types within forest recultivation plots. Their share in all non-abundant species was $5.87 \%$ (loess-like loam type), $2.77 \%$ (Calcic Chernozem topsoil type on a loess-like loam interlayer), and 8.58\% (Calcic Chernozem topsoil on sand interlayer). Thus, abundant species were found to be prevailing in the dominating structure of oribatid mite populations within forest recultivation plots. Among those, general species represented $25.4 \%$ and $47.6 \%$ of the bulk. Such dominating structure reveals unfinished formation of the oribatid mite population in different stratigraphic types within forest recultivation plots.

\section{CONCLUSIONS}

Activity of oribatid mites in soil ecosystems provides stability of soil ecological properties (fertility, soil structure), which complies with ecosystem service groups such as pedogenesis and soil quality regulation. Within soil recultivation plots, oribatid mites promote ecological rehabilitation of technogenically-disturbed ecosystems, thus supporting biogeochemical cycles and bulk soils productivity.

The species structure of oribatid mites is a major factor for the biological variety of soil and indicates the state of its population as an element of soil zoocenosis. Our study determined that the amount of oribatid mite species under the red cedar within the studied stratigraphic types of forest recultivation varied from 17 to 26. At the same time, the population density of oribatid mites varied from 1820 to 2887 ind. $/ \mathrm{m}^{2}$, which, according to literature data, indicates a high soil mass aggregation rate, along with a high amount of pores and casts found during the evaluation of micro-organization of bulk soils within the forest recultivation plots.

Compared to loess-like loam, lower species abundance (17 and 19, accordingly) and a high density of oribatida (2887 and $2333 \mathrm{ind} . / \mathrm{m}^{2}$, accordingly) were registered in the Calcic Chernozem topsoil with loess-like loam interlayer and with sand interlayer. These findings were confirmed by the calculation of the Margalef species variety index (2.64 and 3.07, accordingly) compared to the Margalef index calculated for the mite population found on the loess-like loam bulk layer (4.46).

In populations of oribatida of all studied artificial edaphotopes under the red cedar within forest recultivation plots such common species 
as Multioppia (M.) glabra (Mihelčič, 1955) and Ramusella (Rectoppia) mihelcici (Pérez-Íñigo, 1965) were present as environmental conditions were the most favourable for those. High abundance of those species affects the average density of oribatid mite populations within recultivation plots, which is typical of anthropotechnogenic ecosystems.

The composition of fauna in red cedar plantations, in particular their oribatid mites communities, is most common for loess-like loam and Calcic Chernozem topsoil types on loesslike loam interlayer (Jaccard index 59.3\%). It can be explained by the location adjoining these recultivation types.

\section{ACKNOWLEDGEMENTS}

The authors would like to thank the oribatologist, Associated Professor Arthur Shtirts, PhD, for his assistance in identification of collected zoological samples.

Received 17 September 2017

Accepted 14 November 2017

\section{References}

1. Behan-Pelletier VM. Oribatid mite biodiversity in agroecosystems: role for bioindication. Agriculture, Ecosystems and Environment. 1999; 74: 411-23.

2. Belova NA. [Ecology, micromorphology, anthropogenesis of forest soils in the steppe zone of Ukraine]. Dnipropetrovsk: Dnipropetrovsk University Press. 1997. Russian.

3. Bird SB, Coulson RN, Fisher RF. Changes in soil and litter arthropod abundance following tree harvesting and site preparation in a loblolly pine (Pinus taeda L.) plantation. Forest Ecology and Management. 2004; 202(1-3): 195-208.

4. Bulanova-Zakhvatkina EM. [Oribatid mites]. Moscow: Vysshaya shkola. 1967. Russian.

5. Chibrik TS, Lukina NV, Filimonova EI, Glazyrina MA, Rakov EA, Maleva MG, Prasad MNV.
Biological recultivation of mine industry deserts: Facilitating the formation of phytocoenosis in the middle Ural region, Russia. In: Prasad MNV (ed.). Bioremediation and Bioeconomy. Elsevier, 2016. 389-418.

6. Eisenhauer N. The action of an animal ecosystem engineer: identification of the main mechanisms of earthworm impacts on soil microarthropods. Pedobiologia. 2010; 53(6): 343-52.

7. Engelmann HD. Zur Dominanzklassifizierung von Bodenarthropoden. Pedobiologia. 1978; 5/6(18): 378-80.

8. Faly LI, Kolombar TM, Prokopenko EV, Pakhomov OY, Brygadyrenko VV. Structure of litter macrofauna communities in poplar plantations in an urban ecosystem in Ukraine. Biosystems Diversity. 2017; 25(1): 29-38.

9. Gilyarov MS. (ed). [A key to soil-inhabiting mites, Sarcoptiformes]. Moscow: Nauka; 1975. Russian.

10. Gormsen D, Hedlund K, Huifu W. Diversity of soil mite communities when managing plant communities on set-aside arable land. Applied Soil Ecology. 2006; 31(1-2): 147-58.

11. Klymenko G, Kovalenko I, Lykholat Yu, Khromykh N, Didur O, Alekseeva A. The integral assessment of the rare plant populations. Ukrainian Journal of Ecology. 2017; 7(2): 201-9.

12. Kolodochka LA, Shevchenko OS. Diversity and community structure of Oribatidmites (Acari, Oribatei) at memorial complexes of a megapolis. Vestnik zoologii. 2013; 47(4): 291-7.

13. Kul'bachko YL, Didur OO, Loza IM, Pakhomov OE, Bezrodnova OV. Environmental aspects of the effect of earthworm (Lumbricidae, Oligochaeta) tropho-metabolic activity on the $\mathrm{pH}$ buffering capacity of remediated soil (steppe zone, Ukraine). Biology Bulletin. 2015; 42(10): 899-904.

14. Magurran AE. [Ecological diversity and its measurement]. Moscow: Mir; 1992. Russian.

15. Mbaya RP. Land degradation due to mining: the gunda scenario. International Journal of Geography and Geology. 2013; 2(12): 144-58. 
16. Novitskii ML. [Granulometric texture of sulfide subsurface rock fine grained soil and mine spoil technogenic substrates]. Bulletin of the Nikitsky Botanical Garden. 2011; 103 : 85-87. Russian.

17. Pavlichenko PG. [A guide to the Ceratozetoid mites (Oribatei, Ceratozetoidea) of Ukraine]. Kiev: Institute of Zoology of National Academy of Sciences of Ukraine. 1994. Russian.

18. Smrž J, Norton RA. Food selection and internal processing in Archegozetes longisetosus (Acari: Oribatida). Pedobiologia. 2004; 48(2): 111-20.

19. Shtirts AD. [Evaluation of anthropogenic pressures on ecosystems by using of the integral oribatid mites community's index]. Acta Biologica Sibirica. 2015; 1(1-2): 51-66. Russian.

20. Striganova BR. [Feeding of soil saprophages]. Moscow: Nauka. 1980. Russian.

21. Subías LS, Shtanchaeva UYa, Arillo A. [Checklist of the oribatid mites (Acariformes, Oribatida) of the different world biogeographical regions]. Electronic monograph. 2012. Spanish. (Electronic source http://sea-entomologia. org/Publicaciones/MonografiaElectronica4/ ACARI_ORIBATIDA_MESEA4.pdf)
Yuriy Kulbachko, Oleh Didur,

Yuliia Ovchynnykova

\section{ORIBATIDINIŲ ERKIŲ (ACARI: ORIBATIDA) RŪŠIŲ POPULIACIJOS STRUKTŪRA REGE- NERUOTŲ TERITORIJŲ (UKRAINA) MIŠKO PLANTACIJŲ VIRŠUTINIAME DIRVOŽEMIO SLUOKSNYJE}

\section{Santrauka}

Straipsnyje aprašomas dirbtinių edafotopų tyrimas ivairiuose stratigrafijos tipuose virgininiu kadagiu (Juniperus virginiana L.) apsodintoje regeneruotoje Pavlogrado kasykloje (Pavlogradas, Dniepropetrovsko regionas, Ukraina). Aptarti oribatidinių erkių (Oribatida), kaip pirminių mirusios augalinès medžiagos destruktorių, rūšių populiacijos struktūros bruožai, gerinantys dirvožemio derlingumą. Nustatyta, kad oribatidinių erkių rūšių skaičius tirtuose virgininio kadagyno viršutinio dirvožemio plotuose svyravo nuo 17 iki 26. Vidutinis oribatidinių erkių populiacijų tankis $1820-2887$ ind./m². Visuose tirtuose virgininiu kadagiu regeneruotų miško plotų dirbtiniuose edafotopuose galèjo būti identifikuojamos kai kurios pagrindinès oribatidinių erkių rūšys, tokios kaip Multioppia glabra (Mihelčič) ir Ramusella mihelcici (Perez-Inigo).

Raktažodžiai: aplinkos regeneracija, ekosistema, pedogeneze், miško rekultivavimas, virgininis kadagys (Juniperus virginiana L.), oribatidinès erkès 